\title{
HOW GREEN PERFORMANCE STIMULATES TOURIST LOYALTY? EXAMINING THE ROLE OF RELATIONSHIP QUALITY IN VIETNAM
}

\author{
Anh Tuan PHAM \\ Tay Bac University, Faculty of Social Sciences, Son La, Vietnam, e-mail: phamtuan@utb.edu.vn
}

The Kien NGUYEN*

VNU University of Economics and Business, Center for Socio-Economic Analysis and Databases (CSEAD), Hanoi, Vietnam, e-mail: cseadpaper@gmail.com

Van Anh VU

Thai Nguyen University of Education, Faculty of Geography, Thai Nguyen, Vietnam, e-mail: anhvv@tnue.edu.vn

Canh Huy PHAM

Hanoi University of Science and Technology, School of Economics and Management, Vietnam, e-mail: huy.phamcanh@hust.edu.vn

Trung Thanh LE

VNU University of Economics and Business, Faculty of Finance and Banking, HaNoi, Vietnam, e-mail: letrungthanh127@gmail.com

Thi Van Anh LE

Tay Bac University, Faculty of General, Son La, Vietnam, e-mail: levananh@utb.edu.vn

Thi Hong Nhung NGUYEN

Tay Bac University, Faculty of Social Sciences, Son La, Vietnam, e-mail: nhungnguyen@utb.edu.vn

Khac Lich HOANG

VNU University of Economics and Business, Faculty of Development Economics, Hanoi, Vietnam, e-mail: hoangkhaclich@gmail.com

\begin{abstract}
Citation: Pham, A.T., Nguyen, T.K., Vu, V.A., Pham, C.H., Le, T.T., Le, T.V.A., Nguyen, T.H.N., \& Hoang, K.L. (2021). HOW GREEN PERFORMANCE STIMULATES TOURIST LOYALTY? EXAMINING THE ROLE OF RELATIONSHIP QUALITY IN VIETNAM. GeoJournal of Tourism and Geosites, 34(1), 202-208. https://doi.org/10.30892/gtg.34127-638
\end{abstract}

\begin{abstract}
The main purpose of this research is to propose and test a conceptual model that clarifies the relationship between green per formance of hotels and customer loyalty with the mediating role of relationship quality. The data collected from 200 homestay tourists in Moc Chau national tourism area, Son La province, Vietnam through questionnaire survey was tested by applying partial least squares with SmartPLS software. Analytical results showed that the higher tourists perceive the homestay green performance, the tighter the relationship quality they have towards the homestays, which in turns stimulates their loyalty behavior. The evidence also indicated that relationship quality contributes as the partial mediator in the relationship between green practice and tourist loyalty. The theoretical and managerial contribution, as well as the limitation and future research direction were also discussed in the paper.
\end{abstract}

Key words: Green performance, relationship quality, tourist loyalty, Vietnam

$* * * * * *$

\section{INTRODUCTION}

Tourism which is one of the most developed economic sectors in recent years, has contributed a lot of works for the economy of almost all countries all over the world. Economists indicated that the development of society and economy stimulates the high and diversifying demand of customers for the tourist services such as natural tourism, psychical tourism, cultural tourism etc. For this reason, many countries have built a tourism - based country development strategy for the future. But this sector is also very sensitive and slight that is influenced by a lot of factors: nature, customer, socio culture and politics. For instance, Covid-19 pandemic has affected this sector in a global sphere. This in turn causes a big impact on the economy of all the countries in the world. Moreover, environmental issues have been global issues which influence seriously our world, including Vietnam - an industrialized country. Nowadays humans are facing with the global warming, deforestation and pollution (water, air and sound) so they have tendency to return to the nature and protect the nature for our future generation.

Vietnam which is a developing country in the Southeast of Asia, has marked to the world with high economic growth rates in the recent years. With the openness and development policy of Vietnamese government from 1986, Vietnam economy has been developed in an impressive manner. For instance, the GDP per capita has increased annually with USD 2,715 (2019) in comparison with 96,343 (1989) as the number of World Bank ${ }^{1}$. In term of tourism, Vietnam is a country with very rich and diverse tourism resources, many natural landscapes, long and beautiful beaches as well as many unspoiled natural areas. Specifically, many places have been recognized as world natural heritage such as Son Doong cave, Ha Long Bay. Therefore, green tourism (sustainable tourism) is not only a phenomenon but also an urgent requirement for the country's sustainable development to meet the needs of the times. To concretize that requirement, the Vietnamese tourism industry proposed a set of criteria for sustainable tourism development, namely, the Green Lotus label which includes 81 criteria with a total of 154 points and 25 bonus points, divided into 3 levels: junior level ( 30 criteria), incentive level ( 29 criteria) and advanced level ( $22 \mathrm{criteria})$.

Because of the emerging topic, recently, there are a lot of research on this issue such as research of (Han et al., 2018; Martínez, 2015; Merli et al., 2019; Yusof et al., 2017). Yusof et al. (2017) indicated that environmental management practice do not have significant effect on

\footnotetext{
* Corresponding author
}

${ }^{1}$ World Bank Group - International Development, Poverty, \& Sustainability 
customer loyalty directly but indirectly via customer satisfaction. Besides, Martínez (2015) showed that green image has both direct effect on customer loyalty and indirect impact through green trust and green satisfaction. Han et al. (2018) in the same vein found that hotel practice of water conservation management and hotel practice of waste reduction management influence on guest participation intention for green hotel practices and guest loyalty intention for green hotel via hedonic value and utilitarian value. This research context is in Vietnam. Moreover, in the research of Merli et al. (2019), the authors explained why hotels should go green by confirming that green practices performances directly influence on loyalty towards the hotel, loyalty towards the green hotel and satisfaction. Even the significant contribution to the literature and pratice, the authors indicated that it is necessary to deeper examine relationship between hotel green practices and customer loyalty by adding other variables in term of giving a comprehensive mechanism of customer behavior in tourist industry.

Moreover, as noted above Vietnam tourism is now very developing with many types such as natural tourism, cultural tourism, social tourism, entertainment tourism, sportive tourism, spiritual tourism (Han et al., 2018). But to date, in Vietnam, almost all of the research applied macro approach in term of giving the suggestion for government and tourist industry, very little research focuses on the customer behavior (such as loyalty) in the correlation with green performance. As suggested by Trang et al. (2019), there is a need to deeper examine the crucial role of relationship quality in the relationship between green hotel and customer behavior (Trang et al., 2019). So that this research aims to fill this gap by proposing and empirical testing the relationship between green performance of homestay and tourist loyalty in the context of Vietnam. In addition, this research also clarifies the role of tourist - hotel relationship quality (trust, satisfaction and commitment) in this relationship to shed light on the importance of green performance in the customer percep tion.

To reach the end, this research is based on the trust - commitment theory and select the context of natural tourism in Moc Chau national tourist area. Because this area is among the most famous natural tourist places in Vietnam where attracts a lot of tourists both domestic and international each year. According to the authorities, most tourists visiting Moc Chau are young and have high level of education which lead them to a high level of environmental perception. Moreover, recent years, with the sustainable development tourist strategy of provincial authority, there are a lot of environment friendly services such as green homestay. To evaluate the efficiency and contribute to the literature and practice, this research attempts to answer research questions as followe

First, to what extent does green performance of homestay influence tourist loyalty?

Second, to what extent does tourist - homestay relationship quality influence tourist loyalty?

Third, how does tourist - homestay relationship quality influence the relationship between green performance and tourist loyalty?

The remaining of this paper is arranged as follows. After introduction section is the background theories and hypothesis development. The third section is the data collection which is continued with data analysis section. This paper finishes with the conclusion and discussion section.

\section{BACKGROUND THEORY AND HYPOTHESIS DEVELOPMENT}

\section{Trust - commitment theory}

The commitment - trust theory questioned this central hypothesis in view of relationship in strategic alliances (Morgan and Hunt, 1994). Focusing on what makes relationship marketing successful, the commitment - trust theory considered trust and relationship commitment as the key factors in building and maintaining successful relationship. This theory is first applied in psychological area but nowadays this theory has been utilized in a lot of fields such as management (Casimir et al., 2012; Kwon and Suh, 2005), marketing (Brown et al., 2019; Solberg and Nes, 2002). According to the theory, trust and relationship commitment are central to successful firms, because they encourage positive customers behavior (Park et al., 2017; Zhang et al., 2015).

In the tourist industry, previous research applied this theory to explain the relationship between relationship perception and destination loyalty (Su et al., 2017), corporate image and tourist loyalty through mediating effect of tourist satisfaction and commitment (Richard and Zhang, 2012), customer engagement and brand loyalty (So et al., 2016). Previous research also showed the relationship between organizational identification and its outcomes via employee trust and commitment (Edwards and Peccei, 2010; Thomas, 2015). They also indicated the correlation between CSR and employee trust and commitment (Collier and Esteban, 2007; Farooq et al., 2014; Turker, 2009). In summary, this theory has been utilized vastly in the tourist industry because of its usefulness. Therefore this research also applies this theory to clarify the relationship between green performance and customer loyalty with the mediation of relationship quality.

\section{Green performance of homestay}

In this research green performance of homestay (GP) can be understood as the process and procedures performed by the homestay by which all activities are friendly with the environment (Yusof et al., 2017). By this definition, GP means all the activities of homestay minimizing the negative impact for the environment around. So that, green homestay is an environment - friendly lodging properties performing a lot of strategy and activities to minimize harmful to the environment (Verma and Chandra, 2018). These actions can be energy efficiency utilization, solid waste policy, water conservation, efficient lighting. Other green activities are eco-cuisine and using electronics as an email, using more Internet and paperless activities. One of the most use in hotel is electronic consumption, especially in the condition of heating and refrigerator utilization. Therefore, most hotels are now using a system whereby, when guests leave the room, all the energy appliances will shut down except for refrigerators, alarm clocks and other essential appliance. This is because customers often simply leave the room without switching off the appliances (Alexander, 2002) As noted above, environment - related for product and services are now the serious demand of the society (Namkung and Jang, 2017). To satisfy this demand, the management of hotel have to understand and perform well this issue in the practice (Han et al., 2011). Previous research indicated that green performance is considered as a competitive advantage for the hotel which leads to customer accepting a premium price and revisit intention in the future (Kim et al., 2017).

In the same vein, they indicated that GP stimulates customer loyalty for the hotel (Yusof et al., 2017) or customer willingness to pay (Kang et al., 2012), or pay more for the restaurant if customer perceived the green practice (Namkung and Jang, 2017). The more hotel performs well the green activities, the more customer perceive hotel brand reputation in the practice (Han et al., 2011).

\section{Green performance and customer loyalty}

Customer loyalty is considered among the most important concepts utilized popularly in business and in the marketing field. So that this concept has received a lot of research by scholars because of its crucial role for the firms. This concept is utilized in many industry to examine the customer loyalty to the firms or employee loyalty. This research focused only on the customer loyalty in the tourist and hospitality industry. To date there are many definitions of this concept. Specifically, customer loyalty refers to customer commitment towards products, services (Priporas et al., 2017), towards a destination (Chi and Qu, 2008) or towards a tourist brand (So et al., 2016) or towards a firm. In this research, tourist loyalty is defined as the strength of the relationship between the attitude of tourists towards the green hotel/ homestay which stimulate them to revisit and stay in that hotel/ homestay in their next trips in the future. 
This definition is the same with (Yusof et al., 2017): “customer loyalty is the willingness to keep repurchase of the product and service offered, keep using the same accommodation service which are concerned with the environmental issues and to suggest the service to close friends and families". The literature indicated two facets of customer loyalty, namely behavioral and attitudinal (Yusof et al., 2017). Martínez (2015) confirmed in tourist industry scholars focus more on the attitudinal component (Martínez, 2015). Previous scholars also indicated that the more loyal a tourist is to a hotel, the more profitable to the hotel. Previous research proposed and tested many determinants of customer loyalty in the hospitality and tourist industry such as service quality (Osman and Sentosa, 2013), perceived value (El-Adly, 2019), hotel image and reputation (Lai, 2019). Previous scholars also indicated the importance of social responsibility on customer loyalty (De Grosbois, 2012; Martínez, 2015). As mentioned above, green practice can be considered as the environmental responsivity of the firms, especially tourist firms have to perform well their responsibility towards the environment. Previously it was confirmed the direct effect of green practice to the customer loyalty (Martínez, 2015; Merli et al., 2019; Robinot and Giannelloni, 2010). Theory of social identity showed that tourists go to natural tourism because they have a close identification with the nature and tend to revisit when they have occasion (Lai, 2019). In the same vein, scholars applied the theory of planned behavior and found the importance of moral reflectiveness and conscientiousness on tourist loyalty towards green hotel. So this research proposes that:

\section{H1: Green performance of homestay has positive impact on tourist loyalty.}

\section{Tourist - hotel relationship quality}

Relationship quality has recently emerged as an important concept which has attired a lot of research from both academicians and practitioners in the marketing field because of the intensive competition nowadays (Brown et al., 2019; Collier and Esteban, 2007; Curry and Gao, 2012). This concept has its origin from relationship marketing domain. It aims to build a long-term, trusting, beneficial relationship with the customers (Kwon and Suh, 2005). In other words, the most ultimate purpose of relationship marketing is to build, maintain and strengthen strong relationships with customers. In this research relationship quality is considered as the evaluation of customers about the strengthening and attachment to a firm which can lead them to positive feelings, emotion and behaviors such as respect, courtesy, empathy, and helpfulness (Brown et al., 2019). The key factor in testing the potential for relationship quality is the degree of interaction between customers and firms. Relationship quality has been tested in many research contexts between business to business, business to consumer, industry marketing or service marketing. There are many background theories applied to explain this concept such as social exchange theory, theory of reasoned action and theory of trust - commitment (Morgan and Hunt, 1994). Previous research proposed and indicated a lot of relationship quality dimensions such as trust (Young and Albaum, 2003), trust and commitment (Brown et al., 2019), satisfaction (Martínez, 2015), commitment (Lai, 2019). They also agree that relationship quality is a higher - order construct including many components. By examining the literature in the tourist and hospitality industry, as the suggestion of previous researchers that it is necessary to have a more comprehensive construct of relationship quality, hence this research proposes that this construct is a second - order construct which encompasses of three dimensions, namely, tourist trust, tourist satisfaction and tourist commitment. In which, tourist trust refers to a tourist's confidence in the goodwill and competence of the hotel (Brown et al., 2019). Tourist trust is important in a long temps and profitable relationship. Tourist trust can be divided into cognitive trust and affective trust. Tourist satisfaction refers the tourists' response to the "evaluation of the perceived discrepancy between expected performance and the actual performance in term of services provided by a hotel after its consumption" (Richard and Zhang, 2012). This definition is originated from expectation - confirmation theory which has been applied vastly in research customer satisfaction and loyalty. Moreover, tourist commitment refers to the "belief to the importance of an ongoing relationship that all partners tend to maintain that relationship and in some case they are willing to sacrifice short-term benefits to have long-term ones" (Richard and Zhang, 2012).

Previous research also attempted to examine a lot of relationship quality antecedents such as corporate image (Richard and Zhang, 2012), service provider attributes and orientation (Kim and Cha, 2002), social responsibility (Collier and Esteban, 2007). In the research of Trang et al. (2018), the authors indicated that green attributes stimulates customer trust and satisfaction (Trang et al., 2019). Moreover, previous research also confirmed customer trust, satisfaction and commitment have positive effect on customer loyalty (Brown et al., 2019; El-Adly, 2019; Martínez, 2015). In the same vein, theory of trust - commitment showed that trust and commitment positively influence on customer loyalty, customer word-of-mouth or citizenship behavior (Han et al., 2018). From these evidence, this research propose that:

H2: Green performance of homestay has positive impact on tourist - homestay relationship quality.

H3: Tourist - homestay relationship quality positively influence on tourist loyalty.

\section{The mediation of tourist - homestay relationship quality}

Previous researchers showed that corporate social responsibility can both influence on customer loyalty both directly and indirectly through customer trust, satisfaction and identification (Martínez and Del Bosque, 2013), involvement and commitment (Inoue et al., 2017), commitment (Collier and Esteban, 2007), trust and commitment (Brown et al., 2019), satisfaction (Kim and Cha, 2002), relationship quality (Richard and Zhang, 2012). They also considered green practice as a part of corporate social responsibility, namely environment responsibility. Recent research also examine the mediation of relationship quality in the hospitality and tourism industry (El-Adly, 2019; Lai, 2019; Merli et al., 2019). From these evidence, the hypothesis of this research is that:

H4: The relationship between green performances of homestay on tourist loyalty is mediated by tourist - homestay relationship quality.

From these hypotheses, the research model is depicted in Figure 1 as follow:

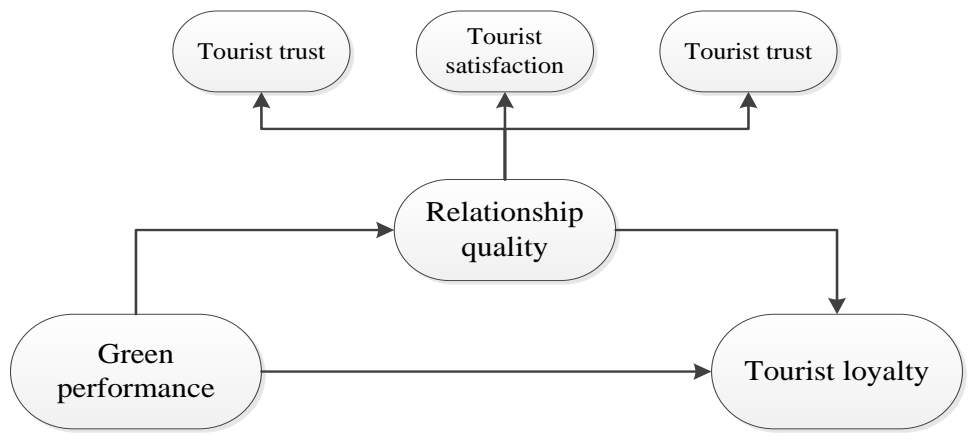

Figure 1. Research model

\section{RESEARCH METHOD \\ Questionnaire design}

To test the proposed hypothesis, this research utilizes the questionnaire survey method to collect the data. Participants are tourists who visit Moc Chau NTA and stay in the community hospitality, called homestay. The authors selected this kind of respondents because they experienced already the homestay services and they can perceive to which extent that homestay applied and performed the green activities in the reality which can lead them revisit or not that hotel. The current research applied scales from previous studies and modified to fit the new context of green tourism in Vietnam. 
All scales are in the form of Likert-5 which range from 1 representing totally disagree to 5 representing totally agree. In which, tourists' perception of green performance includes of 8 items adopted from (Lee et al., 2018; Yusof et al., 2017); tourist - hotel relationship quality is measured by tourist trust with 4 items applied from (Ponnapureddy et al., 2017; Su et al., 2017), tourist satisfaction with 3 items adopted from (Merli et al., 2019; Robinot and Giannelloni, 2010); tourist commitment with 4 items from (De Grosbois, 2012; Rahman and Reynolds, 2016) and tourist loyalty behavior with 3 items modified from (Merli et al., 2019; Yusof et al., 2017).

To have a more consistent questionnaire, we applied back - translation technique by specialists in English and marketing. That means the original English items were translated into Vietnamese and then translated back to English, the specialists in English and marketing compared the two versions and modified to have a draft version. This draft version is tested and checked with 10 tourists in a pilot test and then the final version of questionnaire was fixed.

\section{Data collection}

The main aim of this research is to evaluate the loyalty behavior of tourists who stayed in a green homestay that means the ability of revisit and re-stay in that homestay. So the population for this research is all the tourists who have visited Moc Chau national tourist are a. Moc Chau NTA, belonging to Moc Chau district, Son La province, $180 \mathrm{~km}$ from Hanoi, $120 \mathrm{~km}$ from Son La city, is approved by the Prime Minister on the Planning as a national tourist area in May. 11/2014. These are 2 mountainous districts located on the limestone plateau of the Northwest region with an average altitude of more than $1,000 \mathrm{~m}$ above sea level. There are 12 minority ethnics live together in Moc Chau district with abundant cultures such as clothes, specialties, foods as well as house on stilts.

That means Moc Chau NTA has both natural tourism resources and humanity resources which is the basement to develop sustainable tourist industry. The authors applied a simple random sampling method through questionnaires at this area. The questionnaire consisted of 22 main questions, so according to (Hair et al., 1998) the minimum sample size would be 110 questionnaires. To collect the most appropriate responses, the research team selected 11 homestays at Moc Chau NTA and 20 respondents for each homestay. This study was deployed during one month. Finally, the result has a total of 200 valid questionnaires collected after the survey, means the rate about 90.9\%. The demographics of the respondents is depicted as follows:

Table 1. Demographic information of respondents

\begin{tabular}{|c|c|c|c|}
\hline Factors & Component & Amount & $\%$ \\
\hline \multirow{2}{*}{ Gender } & Male & 95 & 47.5 \\
\hline & Female & 105 & 52.5 \\
\hline \multirow{4}{*}{ Age } & Under 25 & 31 & 15.5 \\
\hline & $25-35$ & 70 & 35.0 \\
\hline & $36-45$ & 73 & 36.5 \\
\hline & Over 45 & 26 & 13.0 \\
\hline \multirow{4}{*}{$\begin{array}{l}\text { Yearly income } \\
\text { (USD) }\end{array}$} & Under 2000 & 15 & 7.5 \\
\hline & $2000-3000$ & 117 & 58.5 \\
\hline & $3000-5000$ & 52 & 26.0 \\
\hline & Over 5000 & 16 & 8.0 \\
\hline \multirow{4}{*}{ Education } & High school & 76 & 38.0 \\
\hline & College & 12 & 6.0 \\
\hline & University & 107 & 53.5 \\
\hline & Other & 5 & 2.5 \\
\hline
\end{tabular}

Notes: The per capita income in Vietnam (2020) is
Table 2. Measurement model evaluation

\begin{tabular}{|l|c|c|c|}
\hline Variables & AVE & CR & C $\boldsymbol{\alpha}$ \\
\hline Green practice performance & 0.50 & 0.88 & 0.85 \\
\hline Loyalty & 0.61 & 0.83 & 0.70 \\
\hline Satisfaction & 0.69 & 0.87 & 0.78 \\
\hline Trust & 0.66 & 0.89 & 0.83 \\
\hline Commitment & 0.63 & 0.87 & 0.80 \\
\hline
\end{tabular}

Table 3. Construct AVE correlation

\begin{tabular}{|l|c|c|c|c|c|}
\hline & GP & COM & LOY & SAT & Trust \\
\hline GP & 1 & 0 & 0 & 0 & 0 \\
\hline COM & 0.25 & 1 & 0 & 0 & 0 \\
\hline LOY & 0.34 & 0.39 & 1 & 0 & 0 \\
\hline SAT & 0.17 & 0.25 & 0.29 & 1 & 0 \\
\hline Trust & 0.38 & 0.37 & 0.31 & 0.26 & 1 \\
\hline
\end{tabular}

\section{RESEARCH RESULTS}

This study applied the PLS-SEM path model to test hypotheses through Smart PLS 2.0 software (Hair Jr et al., 2016). Compared with other empirical analytical methods, the proposed research model is the most suitable for this method because it focuses on predicting and explaining the complex relationship between the variables in the model and consistent with the small research sample $(\mathrm{n}=200)$. Furthermore, it can explain a relationship of reflective construct and formative construct. In the model, relationship quality is a formative construct and is indirectly formed from 3 reflective constructs that are tourist trust, tourist satisfaction and tourist commitment.

\section{Scales measurement evaluation}

To evaluate the scales, the current research used Cronbach's alpha $(\mathrm{C} \alpha)$, composite reliability $(\mathrm{CR})$ and average extracted variance (AVE). In which, the minimum loading factor is 0.63 and the highest is 0.88 , satisfying the cut-off value 0.5 . Besides, values of $\mathrm{C} \alpha$ ranging from 0.70 to 0.85 and values of CR ranging from 0.83 to 0.89 are both greater than the level 0.7 (Bagozzi and Yi, 1988). These evidence confirm the reliability of the scales satisfying the requirements. In addition, AVE values from 0.50 to 0.69 both satisfy cut - off value of 0.5 (Fornell and Larcker, 1981), indicating that the convergence value is satisfactory (Table 2). To test discriminant validity, this research first used the AVE value of each variable in the correlation to other variables (the Fornell - Larcker criteria). Then, the analytical results showed that the square root of AVE is greater than the correlation coefficient with other variables, demonstrating that the scales ensure discriminant validity (Table 3 ).

\section{Evaluation of structural model}

After evaluating the scales by testing reliability, convergence and discriminant validity, the authors applied the PLS-SEM model to test the relationship of variables using SmartPLS software. The results of the relationships are shown in Figure 2. The results of data analysis show that the relationship quality between tourists - homestay is a second - order construct including of tourist trust, tourist satisfaction and tourist commitment. In which, tourist trust representing $71.9 \%$ of variance $(\beta=0.84)$, tourist commitment representing $53.3 \%$ of variance $(\beta$ $=0.73$ ) and tourist commitment representing $51.2 \%$ of variance $(\beta=0.72)$. The results also showed that green performance of homestay has a significant effect on tourist loyalty $(\beta=0.52 ; \mathrm{p}<0.001$, t $\mathrm{t}$-value $=11.98)$. Moreover, the green performance of homestay has positive impact on the tourist - homestay relationship quality $(\beta=0.73 ; \mathrm{p}<0.001$, t-value $=14.64)$, which in turns influences tourist loyalty $(\beta=0.25 ; \mathrm{p}<0.01, \mathrm{t}$ value $=2.37$. These evidence showed that hypotheses H1, H2 and H3 are supported. To test the mediating effect of tourist - homestay relationship quality in the relationship between green performance and tourist loyalty, a mediation model was built (Bagozzi and Yi, 1988) with bootstrapping test in SmartPLS (Hair Jr et al., 2016) and with Sobel test (Hayes, 2009). The testing results are showed in Figure 3.

In Figure 3, green performance of homestay had a significant impact on tourist loyalty $(\beta=0.688, p<0.001, T$-values $=13.12)$ in the direct model. The influence of green performance of homestay on tourist loyalty decreased in the indirect model $(\beta=0.52 ; \mathrm{p}<0.001, \mathrm{t}-\mathrm{value}$ 
$=11.98)$. In addition, Sobel mediation test results with one-tailed probability and two - tailed propability is smaller than 0.05 threshold (Hayes, 2009). This outcomes expressed that green performance of homestay on loyalty is partially mediated by the influence of tourist homstay relationship quality. This evidence confirmed the hypothesis $\mathrm{H} 4$.

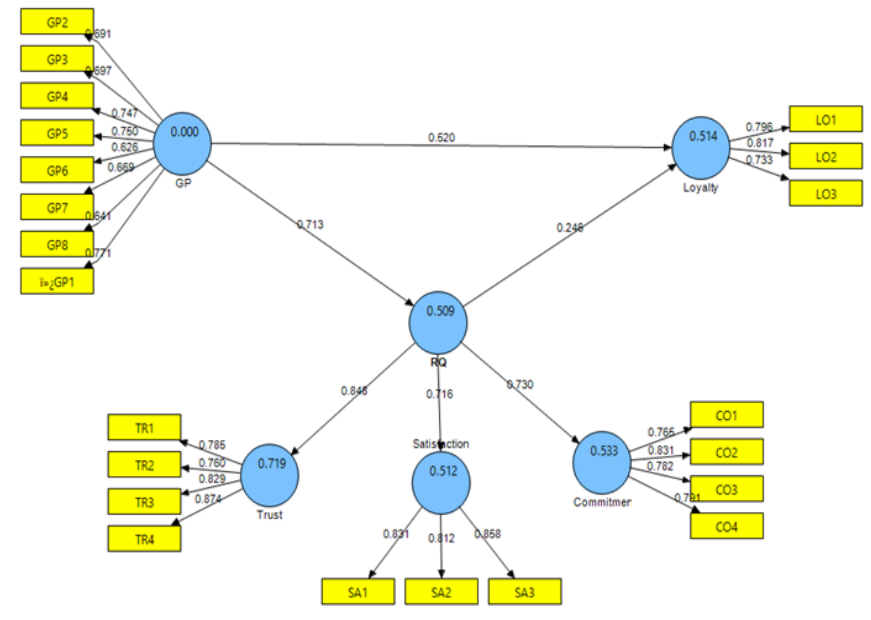

Figure 2. PLS testing results

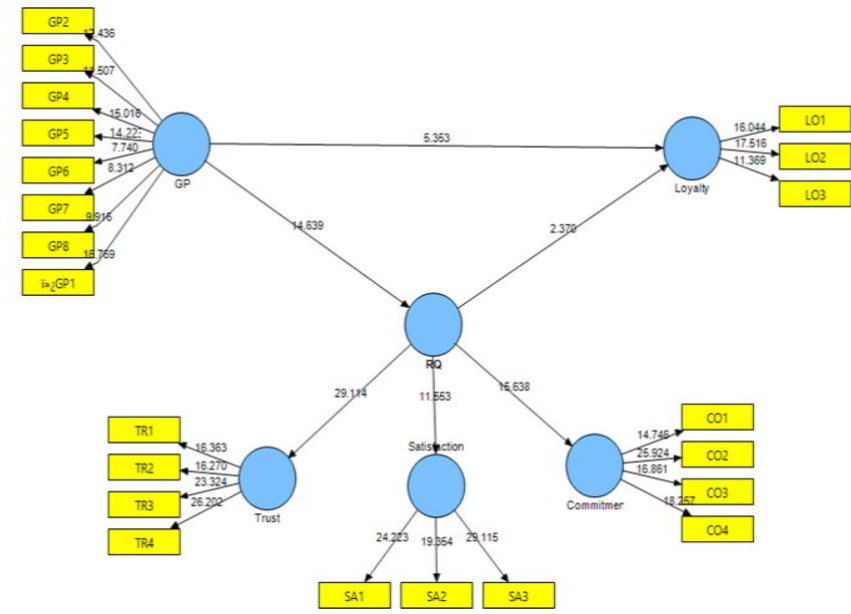

Figure 3. Mediating effect testing

\section{CONCLUSION AND DISCUSSION}

In the context of rapid economic and social development, human needs are increasing, not only at a basic level as before but also at a higher level. After stressful working hours, everyone would like to have trips to rest and explore the world. Many of them choose natural tourism in order to return to the "mother nature", to be immersed in beautiful nature. Therefore, as life quality is increasing, people have to face with the pollution and four concrete walls in urban areas, they desire to be in truly natural places. This poses for hotel managers to understand the needs of their customers, provide a truly natural accommodation, with environmentally friendly products. This is the premise for the development of the business in accordance with the needs of customers as well as the sustainable strategy orientation in tourism of the local government. This study attempts to clarify the tourists' perceptions of homestay green practice performances, thereby assessing and examining its role in the correlation with their loyalty behavior. Research shows that tourists have a very strict requirement on green performance for homestays including 8 items related to all services in the homestay. This fact becomes a criterion that plays a crucial role in stimulating customers' loyal behavior to that homestay. As analytical results, the higher level of perception of green practice performance, the higher the tourists have tendency to loyalty $(\beta=0.52 ; \mathrm{p}<0.001, \mathrm{t}$-value $=11.98)$. The current research contributes the new knowledge to the literature in the hospitality and tourist industry. This research also confirms the relationship between green practices at homestays in promoting positive behavior of tourists (such as loyalty) (Merli et al., 2019; Yusof et al., 2017).

In addition, the current research also clarifies the relationship between customer perceptions of homestay green practices and the tourist homestay relationship quality. In this study, tourist - homestay relationship quality includes three components: tourist trust, tourist satisfaction and tourist commitment. In which, customer trust plays the most important role in this construct. This evidence confirms that trust is the first factor which is very important in the social relationship (Han et al., 2011; Ponnapureddy et al., 2017). Tourist commitment and satisfaction are in second and third place in this construct. Therefore, in order to create positive tourist behavior, homestay needs to build tourist trust, tourist commitment as well as tourist satisfaction. This research also indicates that green practices performances contribute as a basement to help hotel building and maintaining relationship quality with customer. In particular, data analysis results show that the green performance has a strong effect on the relationship quality $p(\beta=0.73 ; p<0.001$, t-value $=14.64)$. This finding contributes greatly to the literature in the hospitality and tourist industry. This is among the first research focusing on the tourists - homestays relationship quality in the relation with the green practice. Furthermore, the current research shows that through the quality of the relations hip between tourists and homestays, tourists tend to be more loyal to the homestay $(\beta=0.25 ; \mathrm{p}<0.01$, t-value $=2.37)$. This evidence contributes to the literature in the hospitality industry and give a more comprehensive understanding in comparison with previous studies focusing on the correlation between relationship quality in promoting customer loyalty behavior (Han et al., 2018; Merli et al., 2019; Robinot and Giannelloni, 2010).

Finally, this research attempts to propose and test the role of the tourist-homestay relationship quality on the effect of tourists' perception of green performance on tourist loyalty behavior. As mentioned above, in this study the tourist-homestay relationship quality includes three components of tourist trust, tourist satisfaction and tourist commitment. In contrast to most previous research which only analyzed the role of each of these individual components in the relationship between green active practices and loyalty (Martínez, 2015; Merli et al., 2019). This research shows that the effect of tourists' perception of green performance on tourist loyalty behavior is partially mediated by the touristhomestay relationship quality. This is an important finding in providing tourism with a more holistic view of this relationship.

Beside theoretical contribution, this research also has some managerial contribution to managers and policy makers.

Firstly, this research suggests that hotel managers in general, homestay in particular need to understand the importance of the "green" factor by performing green practice actions in the hospitality and tourist industry. Because this factor has a direct effect on customer behavior, especially customer loyalty. Scholars pointed out that the cost of acquiring new customers is much higher than maintaining loyal ones (Curry and Gao, 2012). Moreover, loyal customers not only will continue to revisit and utilize services next times, but also becoming a marketer, a citizen for the hotel free but highly effective way, helping the hotel to build brand reputation.

Secondly, this research indicates the important role of relationship quality to customer loyalty. This research suggests to managers of hotels the necessary to build good relationship quality with customers. Specifically, building and maintaining customers' trust in the firm's products and services, thereby improving customer satisfaction and building customer commitment. Performing well green activities is one of the factors that help businesses have a good relationship with customers. Through this relationship, firm can create and maintain customer positive behavior such as citizenship behavior, revisit, repurchase or recommendation and loyalty.

Thirdly, this research asserted that customer - firm relationship quality contributes as the partial mediators between customers' perception about green performance of hotels and customer loyalty. This finding helps managers understand about the mechanism of customer 
loyalty in correlation with green practice performance. That means, green activities not only directly stimulate customer loyalty and also indirect effect via the relationship quality. So that, managers can have appropriate strategies and marketing policies to promote customer loyalty.

Finally, the current research provides some suggestions for tourism policy makers and local tourism authorities in developing natural tourism, ecological tourism or green tourism. This research indicated that when tourism firms perform well green activities, they can help attract more tourists, thereby promoting the development of local tourism, bringing income to local people, and improving the quality of life. Therefore, policy makers need to have specific policies on green tourism development as well as supporting and encouraging tourist firms and other related services to apply and realize well green activities in their daily activities.

Even the theoretical and practical contributions, this research still has some limitations. First, this research only collected the data from tourists who visited and stayed in homestay services in Moc Chau national tourism area, which may lead to incomplete and unrepresentative Vietnamese tourists. Further research could expand the investigated area to have a more complete and compreh ensive research sample. Second, the current research did not mention some of the variables that could moderate these relationships, such as gender, income, age, and education level. This suggests further research could clarify and give a more comprehensive understanding of the relationship between green performance and customer behavior. This research only analyzes relationship quality which is considered as a second - order construct that includes three components: tourist trust, tourist satisfaction and tourist commitment, but has not been analyzed as a first - order construct to have a more comprehensive understanding. Moreover, future studies could also propose new factors to enrich the knowledge on this topic in the current competitive context.

\section{Acknowledgments}

This work was supported by the Ministry of Education and Training, Vietnam (Grant agreement number CT.2019.06.06).

\section{REFERENCES}

Bagozzi, R.R., \& Yi,Y. (1988). On the Evaluation of Structural Equation Models. Journal of the Academy of Marketing Science, 16(1). https://doi.org/00920703/88/1601-0074

Brown, J.R., Crosno, J.L., \& Tong, P.Y. (2019). Is the theory of trust and commitment in marketing relationships incomplete? Industrial Marketing Management, 77, 155-169. https://doi.org/10.1016/j.indmarman.2018.10.005

Casimir, G., Lee, K., \& Loon, M. (2012). Knowledge sharing: influences of trust, commitment and cost. Journal of knowledge management. https://doi.org/10.1108/13673271211262781

Chi, C.G.Q., \& Qu, H. (2008). Examining the structural relationships of destination image, tourist satisfaction and destination loyalty: An integrated approach. Tourism Management, 29(4), 624-636. https://doi.org/10.1016/j.tourman.2007.06.007

Collier, J., \& Esteban, R. (2007). Corporate social responsibility and employee commitment. Business ethics: A European review, 16(1), 19-33. https://doi.org/10.1111/j.1467-8608.2006.00466.x

Curry, N., \& Gao, Y. (2012). Low-cost airlines-A new customer relationship? An analysis of service quality, service satisfaction, and customer loyalty in a low-cost setting. Services Marketing Quarterly, 33(2), 104-118. https://doi.org/10.1080/15332969.2012.662457

De Grosbois, D. (2012). Corporate social responsibility reporting by the global hotel industry: Commitment, initiatives and performance. International Journal of Hospitality Management, 31(3), 896-905. https://doi.org/10.1016/j.ijhm.2011.10.008

Edwards, M.R., \& Peccei, R. (2010). Perceived organizational support, organizational identification, and employee outcomes. Journal of Personnel Psychology. https://doi.org/10.1027/1866-5888/a000007

El-Adly, M.I. (2019). Modelling the relationship between hotel perceived value, customer satisfaction, and customer loyalty. Journal of Retailing and Consumer Services, 50, 322-332. https://doi.org/10.1016/j.jretconser.2018.07.007

Farooq, O., Payaud, M., Merunka, D., \& Valette-Florence, P. (2014). The impact of corporate social responsibility on organizational commitment: Exploring multiple mediation mechanisms. Journal of business ethics, 125(4), 563-580. https://doi.org/10.1007/s10551-013-1928-3

Fornell, C., \& Larcker, D.F. (1981). Evaluating structural equation models with unobservable variables and measurement error. Journal of marketing research, 39-50. https://doi.org/10.1177/002224378101800104

Hair, J.F., Black, W.C., Babin, B.J., Anderson, R.E., \& Tatham, R.L. (1998). Multivariate data analysis (Vol. 5), Prentice hall Upper Saddle River, NJ.

Hair Jr, J.F., Hult, G.T.M., Ringle, C., \& Sarstedt, M. (2016). A primer on partial least squares structural equation modeling (PLS-SEM): Sage Publications.

Han, H., Hsu, L.T.J., Lee, J.S., \& Sheu, C. (2011). Are lodging customers ready to go green? An examination of attitudes, demographics, and eco-friendly intentions. International Journal of Hospitality Management, 30(2), 345-355. https://doi.org/10.1016/j.ijhm.2010.07.008

Han, H., Lee, J.S., Trang, H.L.T., \& Kim, W. (2018). Water conservation and waste reduction management for increasing guest loyalty and green hotel practices. International Journal of Hospitality Management, 75, 58-66. https://doi.org/10.1016/j.jhm.2018.03.012

Hayes, A.F. (2009). Beyond Baron and Kenny: Statistical mediation analysis in the new millennium. Communication monographs, 76(4), 408-420. https://doi.org/10.1080/03637750903310360

Inoue, Y., Funk, D.C., \& McDonald, H. (2017). Predicting behavioral loyalty through corporate social responsibility: The mediating role of involvement and commitment. Journal of business research, 75, 46-56. https://doi.org/10.1016/j.jbusres.2017.02.005

Kang, K.H., Stein, L., Heo, C.Y., \& Lee, S. (2012). Consumers' willingness to pay for green initiatives of the hotel industry. International Journal of Hospitality Management, 31(2), 564-572. https://doi.org/10.1016/j.ijhm.2011.08.001

Kim, W.G., \& Cha, Y. (2002). Antecedents and consequences of relationship quality in hotel industry. International Journal of Hospitality Management, 21(4), 321-338. https://doi.org/10.1016/S0278-4319(02)00011-7

Kim, W.G., Li, J., Han, J.S., \& Kim, Y. (2017). The influence of recent hotel amenities and green practices on guests' price premium and revisit intention. Tourism economics, 23(3), 577-593. https://doi.org/10.5367/te.2015.0531

Kwon, I.W.G., \& Suh, T. (2005). Trust, commitment and relationships in supply chain management: a path analysis. Supply chain management: an international journal. https://doi.org/10.1108/13598540510578351

Lai, I.K.W. (2019). Hotel image and reputation on building customer loyalty: An empirical study in Macau. Journal of Hospitality and Tourism Management, $38,111-121$. https://doi.org/10.1016/j.jhtm.2019.01.003

Lee, S., Sun, K.A., Wu, L., \& Xiao, Q. (2018). A moderating role of green practices on the relationship between service quality and customer satisfaction: Chinese hotel context. Journal of China Tourism Research, 14(1), 42-60. https://doi.org/10.1080/19388160.2017.1419897

Martínez, P. (2015). Customer loyalty: exploring its antecedents from a green marketing perspective. International Journal of Contemporary Hospitality Management. https://doi.org/10.1108/IJCHM-03-2014-0115

Martínez, P., \& Del Bosque, I.R. (2013). CSR and customer loyalty: The roles of trust, customer identification with the company and satisfaction. International Journal of Hospitality Management, 35, 89-99. https://doi.org/10.1016/j.ijhm.2013.05.009

Merli, R., Preziosi, M., Acampora, A., \& Ali, F. (2019). Why should hotels go green? Insights from guests experience in green hotels. International Journal of Hospitality Management, 81, 169-179. https://doi.org/10.1016/j.ijhm.2019.04.022

Morgan, R.M., \& Hunt, S.D. (1994). The commitment-trust theory of relationship marketing. Journal of marketing, 58(3), 20-38. https://doi.org/10.1177/002224299405800302

Namkung, Y., \& Jang, S. (2017). Are consumers willing to pay more for green practices at restaurants? Journal of Hospitality \& Tourism Research, 41(3), 329-356. https://doi.org/10.1177/1096348014525632 
Osman, Z., \& Sentosa, I. (2013). Mediating effect of customer satisfaction on service quality and customer loyalty relationship in Malaysian rural tourism. International Journal of Economics Business and Management Studies, 2(1), 25-37.

Park, E., Kim, K.J., \& Kwon, S.J. (2017). Corporate social responsibility as a determinant of consumer loyalty: An examination of ethical standard, satisfaction, and trust. Journal of business research, 76, 8-13. https://doi.org/10.1016/j.jbusres.2017.02.017

Ponnapureddy, S., Priskin, J., Ohnmacht, T., Vinzenz, F., \& Wirth, W. (2017). The influence of trust perceptions on German tourists' intention to book a sustainable hotel: A new approach to analysing marketing information. Journal of Sustainable Tourism, 25(7), 970-988. https://doi.org/10.1080/09669582.2016.1270953

Priporas, C.V., Stylos, N., Vedanthachari, L.N., \& Santiwatana, P. (2017). Service quality, satisfaction, and customer loyalty in Airbnb accommodation in Thailand. International Journal of Tourism Research, 19(6), 693-704. https://doi.org/10.1002/jtr.2141

Rahman, I., \& Reynolds, D. (2016). Predicting green hotel behavioral intentions using a theory of environmental commitment and sacrifice for the environment. International Journal of Hospitality Management, 52, 107-116. https://doi.org/10.1016/j.ijhm.2015.09.007

Richard, J.E., \& Zhang, A. (2012). Corporate image, loyalty, and commitment in the consumer travel industry. Journal of Marketing Management, 28(5-6), 568-593. https://doi.org/10.1080/0267257X.2010.549195

Robinot, E., \& Giannelloni, J.L. (2010). Do hotels"'green" attributes contribute to customer satisfaction? Journal of Services Marketing. https://doi.org/10.1108/08876041011031127

So, K.K.F., King, C., Sparks, B.A., \& Wang, Y. (2016). The role of customer engagement in building consumer loyalty to tourism brands. Journal of Travel Research, 55(1), 64-78. https://doi.org/10.1177/0047287514541008

Solberg, C.A., \& Nes, E.B. (2002). Exporter trust, commitment and marketing control in integrated and independent export channels. International Business Review, 11(4), 385-405. https://doi.org/10.1016/S0969-5931(02)00016-1

$\mathrm{Su}, \mathrm{L}$., Hsu, M.K., \& Swanson, S. (2017). The effect of tourist relationship perception on destination loyalty at a world heritage site in China: The mediating role of overall destination satisfaction and trust. Journal of Hospitality \& Tourism Research, 41(2), 180-210. https://doi.org/10.1177/1096348014525630

Thomas W.H.Ng. (2015). The incremental validity of organizational commitment, organizational trust, and organizational identification. Journal of Vocational Behavior, 88, 154-163. https://doi.org/10.1016/j.jvb.2015.03.003

Trang, H.L.T., Lee, J.S., \& Han, H. (2019). How do green attributes elicit pro-environmental behaviors in guests? The case of green hotels in Vietnam. Journal of Travel \& Tourism Marketing, 36(1), 14-28. https://doi.org/10.1080/10548408.2018.1486782

Turker, D. (2009). How corporate social responsibility influences organizational commitment. Journal of business ethics, 89(2), 189. https://doi.org/10.1007/s10551-008-9993-8

Verma, V.K., \& Chandra, B. (2018). An application of theory of planned behavior to predict young Indian consumers' green hotel visit intention. Journal of Cleaner Production, 172,1152-1162. https://doi.org/10.1016/j.jclepro.2017.10.047

Young, L., \& Albaum, G. (2003). Measurement of trust in salesperson-customer relationships in direct selling. Journal of Personal Selling \& Sales Management, 23(3), 253-269. 10.1080/08853134.2003.10749002

Yusof, Y., Awang, Z., Jusoff, K., \& Ibrahim, Y. (2017). The influence of green practices by non-green hotels on customer satisfaction and loyalty in hotel and tourism industry. International Journal of Green Economics, 11(1), 1-14. https://doi.org/10.1504/IJGE.2017.082716

Zhang, K.Z., Benyoucef, M., \& Zhao, S.J. (2015). Consumer participation and gender differences on companies' microblogs: A brand attachment process perspective. Computers in Human Behavior, 44, 357-368. https://doi.org/10.1016/j.chb.2014.11.068 